九州大学学術情報リポジトリ

Kyushu University Institutional Repository

\title{
Canopy Rainfall Interception and Fog Capture by Pinus pumila Regal at Mt. Tateyama in the Northern Japan Alps, Japan
}

Uehara, Yoshitoshi

Kasuya Research Forest I Department of Forest and Forest Products Sciences, Faculty of Agriculture, Kyushu University

Kume, Atsushi

Kyushu University Forest, Kyushu University

http://hdl. handle. net/2324/1956652

出版情報: Arctic, Antarctic and Alpine Research. 44 (1), pp.143-150, 2012-02. Institute of Arctic \& Alpine Research, University of Colorado バージョン:

権利関係 : ๑ 2012 Regents of the University of Colorado 


\section{Canopy Rainfall Interception and Fog Capture by Pinus pumila Regal at Mt. Tateyama in the Northern Japan Alps, Japan}

\author{
Yoshitoshi Uehara* and \\ Atsushi Kume† \\ *Kasuya Research Forest, Department \\ of Forest and Forest Products Sciences, \\ Faculty of Agriculture, Kyushu \\ University, 394 Tsubakuro, Sasaguri, \\ Kasuya-gun, Fukuoka 811-2415, Japan \\ $\dagger$ Corresponding author: Kyushu \\ University Forest, Kyushu University, \\ 394 Tsubakuro, Sasaguri, Fukuoka \\ 811-2415, Japan \\ akume@attglobal.net
}

\begin{abstract}
The importance of fog precipitation in the alpine hydrological processes of Pinus pumila canopy was evaluated on Mt. Tateyama, central Japan. We observed rain and fog precipitation, throughfall, and wind direction and velocity at Jodo-daira $\left(36.566^{\circ} \mathrm{N}, 137.606^{\circ} \mathrm{E}, 2840 \mathrm{~m}\right.$ a.s.1.) for 3 years. During the snow-free period (August and September), mean monthly rain and fog precipitation was $0.45 \mathrm{~mm} \mathrm{~h}^{-1}$ and $0.14 \mathrm{~mm} \mathrm{~h}^{-1}$, respectively. The mean rainfall interception by $P$. pumila canopy was about $48 \%$, which is higher than that of other forest canopies at lower altitudes. During rainfall, the dense canopy intercepts rain and the water evaporates from the needle surfaces. On the other hand, the canopy captured fog precipitation even in the absence of rainfall. The amount of throughfall increased with increasing fog deposition. Using $\delta^{18} \mathrm{O}$ and $\delta \mathrm{D}$ analysis, the mean contribution of fog water to the throughfall was estimated at approximately $35 \%$, consistent with the result from direct measurement. These results indicate that $P$. pumila should have a significant influence on the local hydrological processes of the high mountain ecosystem. The large contribution of fog precipitation can be attributed to the high wind velocity and humidity of the Japan Alps.
\end{abstract}

\section{Introduction}

One of the distinctive features of the Japanese alpine zone (above timberline) is the domination of Pinus pumila Regal, a dwarf coniferous shrub (Yanagimachi and Ohmori, 1991). The presence of $P$. pumila greatly impacts the alpine plant community (Okitsu and Ito, 1983; Wada, 2007). This shrubby pine has creeping branches and does not show monopodial growth (Richardson and Rundel, 1998). P. pumila forms a dense canopy, and the canopy height is about $0.2-3 \mathrm{~m}$. The amount of leaf biomass in the closed canopy of $P$. pumila is about $15-25 \mathrm{t} \mathrm{ha}^{-1}$ (Kajimoto, 1994), and the leaf area index (LAI) exceeds $5 \mathrm{~m}^{2} \mathrm{~m}^{-2}$ regardless of the stand height. These values roughly correspond to those of the evergreen coniferous forest in the subalpine zone, and are much larger than those of Pinus densiflora stands $\left(4-7 \mathrm{t} \mathrm{ha}^{-1}\right)$ and Pinus thunbergii stands $\left(6-12 \mathrm{t} \mathrm{ha}^{-1}\right)$ in the lowlands (Gower et al., 1994). These characteristics suggest that $P$. pumila has high rates of transpiration and photosynthesis in summer. On the other hand, it is known that in the alpine region where $P$. pumila is growing, the soil is frozen in winter and undeveloped, and the development of deep root system is inhibited. Therefore, it is important to reveal how, and from where, a large amount of water is supplied to the tree for it to maintain the large amount of evergreen needles.

In the mountain areas, precipitation can occur in solid or liquid form. In addition to rain, fog has a significant contribution to the local liquid precipitation (Yoshino, 1975; Holder, 2004; Chang et al., 2006). The greatest amount of fog deposition can usually be expected in alpine forests at high altitudes (Wehren et al., 2010). In the Japanese mountain forest areas, sometimes the contribution of fog to the total volume of precipitation exceeds that of rain (Kobayashi et al., 2001; Igawa et al., 2002). Therefore, it is very important to evaluate the fog deposition on $P$. pumila canopy to identify the availability of water resources for tree growth. The canopy of $P$. pumila commonly has a patchy distribution on the ridges and peaks of the high mountains, with canopies adjacent to patches of bare ground or a shorter herbaceous community. Fog precipitation occurs as a result of drifting fog and clouds; and the volume of precipitation is determined by the drift velocity, density of droplets, and attributes of the vegetation that affect the trapping of water from the air (Lovett, 1984). The capture efficiency of fog droplets on P. pumila canopies should be higher than that of other vegetation surfaces because the $P$. pumila canopy surface area per ground area is several times greater than that of other vegetation types. Therefore, hydrological inputs can be expected to differ between areas with and without $P$. pumila.

To our knowledge, no research has been published on the water dynamics of $P$. pumila stands in Japanese mountain areas. In addition to the logistical difficulties of conducting fieldwork on the steep alpine terrain, most $P$. pumila stands are under legal protection in the special preserved areas of national parks, which makes it problematic to install large-scale measurement equipment. To overcome these difficulties, we made special instruments for measuring throughfall during the snow-free period. We also applied analysis of stable water isotopes. Stable isotopes, such as $\delta^{18} \mathrm{O}$ and $\delta \mathrm{D}$, are widely used in hydrology as environmental tracers, because they move with the water itself (Taniguchi et al., 2000). These tracers are very useful to identify the origin of water in the water cycles, and can be used even in the alpine regions (Zhang et al., 2010).

The objectives of this study were (1) to evaluate the basic hydrological inputs in the $P$. pumila canopy on the top of alpine areas in Japan; (2) to estimate the contribution of fog precipitation in the water supply of $P$. pumila; and (3) to evaluate the effects of 

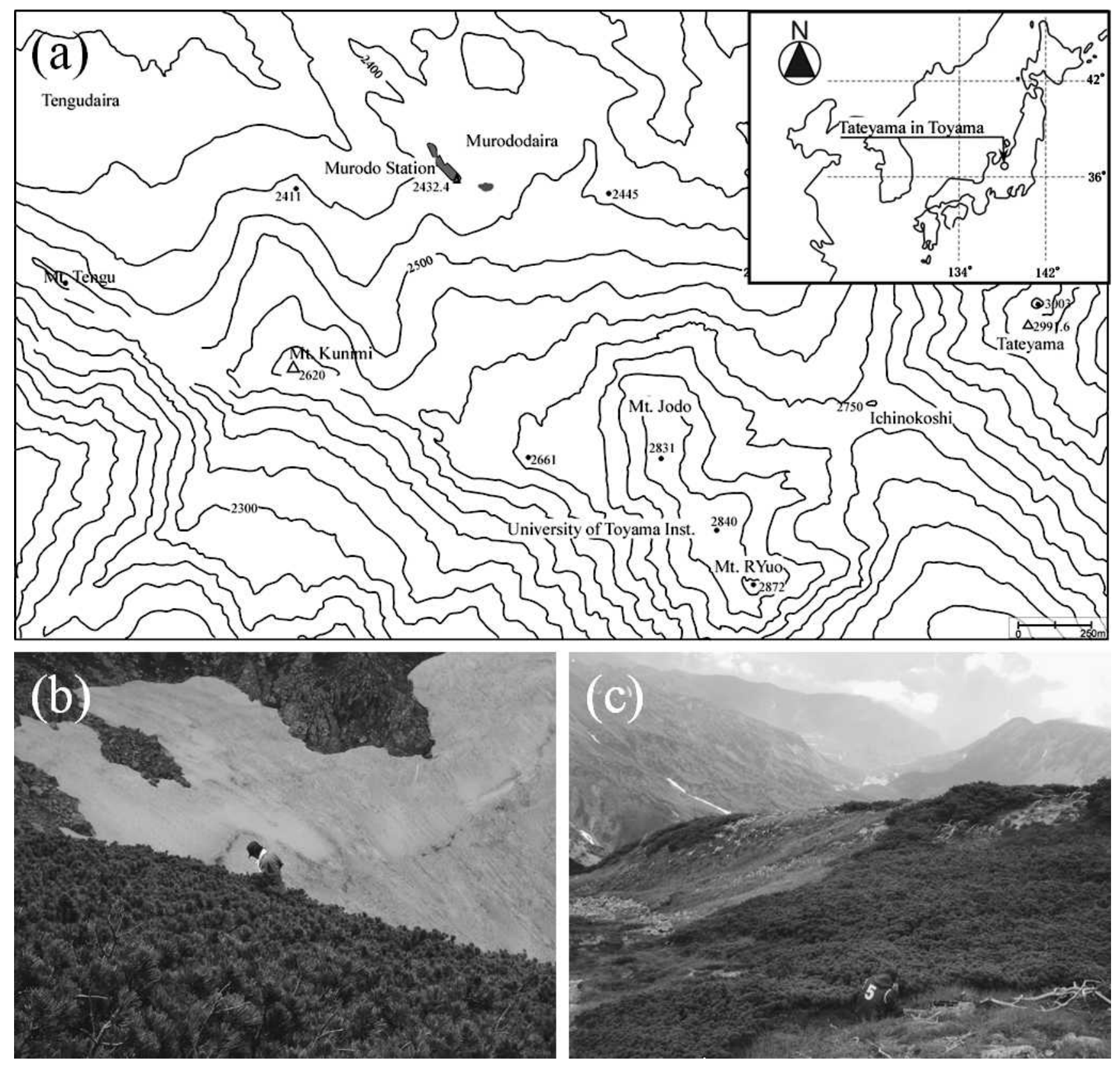

FIGURE 1. (a) The location of the study sites, Mt. Tateyama and Chubusangaku National Park in Japan. (b) North slope site, and (c) southwest slope site.

the $P$. pumila canopy on the local alpine hydrological process during the snow-free period.

\section{Material and Method}

\section{STUDY SITES}

Jodo-daira $\left(36.566^{\circ} \mathrm{N}, 137.606^{\circ} \mathrm{E}, 2840 \mathrm{~m}\right.$ a.s.1.) is one of the peaks in the Hida Mountains in the Northern Japan Alps, Tateyama, and is in the Chubu-Sangaku National Park. The Toyama University research facility with a monitoring tower is located at the top of Jodo-daira for environmental monitoring (Fig. 1, part a). During 2006-2008, the annual mean air temperature at Jodo-daira was $-2.6{ }^{\circ} \mathrm{C}$, and the monthly mean of the daily maximum and minimum air temperatures in August was $13.0^{\circ} \mathrm{C}$ and $8.8^{\circ} \mathrm{C}$, respectively. Jodo-daira consists mainly of three slopes, and the $P$. pumila canopy was distributed continuously on two of three slopes (north: Fig. 1, part b, and southwest: Fig. 1, part c). The height of the canopy was about $0.6 \mathrm{~m}$.

\section{METEOROLOGICAL OBSERVATION}

Air temperature, relative humidity (Pt1000 and capacitance type, CVS-50, Climatec Inc., Tokyo, Japan), wind direction and velocity (Windmill anemometer, 05103, R.M. Young., Traverse City, Michigan, U.S.A.) were measured at the top of the university monitoring tower on Jodo-daira. Two capacitive grid sensors (Capacitive grid sensor, S-LWA-M003, Onset Computer Co., Bourne, Massachusetts, U.S.A.) were also installed at the top of the monitoring tower to observe fog and dew period: one sensor was installed facing upward (the upper surface was mounted at an angle of $45^{\circ}$ from horizontal), another sensor was installed facing 

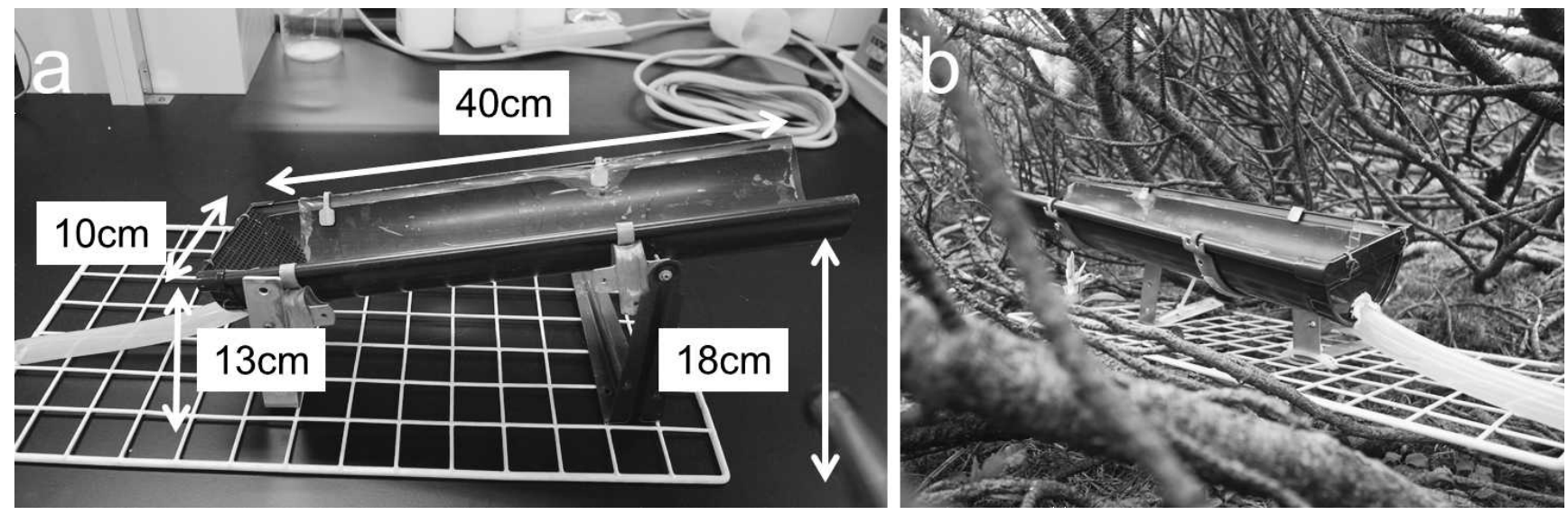

FIGURE 2. (a) The gutter type bulk precipitation collector. (b) The placement of the collector in the pine canopy.

downward (the under surface was mounted at an angle of $315^{\circ}$ from horizontal). To measure rainfall, a $0.2 \mathrm{~mm}$ tipping bucket rain gauge (Rain Collector II, Davis Instruments Co., Hayward, California, U.S.A.) was placed on the monitoring tower. Data on the amounts of precipitation falling in the city of Toyama $\left(36.708^{\circ} \mathrm{N}, 137.202^{\circ} \mathrm{E}, 8.6 \mathrm{~m}\right.$ a.s.1.) and Tateyama (on Tengudaira) $\left(36.582^{\circ} \mathrm{N}, 137.578^{\circ} \mathrm{E}, 2291 \mathrm{~m}\right.$ a.s.l.) were obtained from the Japan Meteorological Agency.

\section{RAIN AND FOG WATER COLLECTION}

Rainwater was collected at the top of the university monitoring tower, and fog water was collected at the base of the tower on Jodo-daira during the snow-free period (late July to early October). Rainwater was collected using a bulk collector, with a 15-cm-diameter polyethylene funnel draining to a $10 \mathrm{~L}$ polyethylene bottle. Fog water was collected using a passive thin string fog sampler (Model FWP-500, Usui Kogyo Kenkyusho Inc, Tokyo, Japan) with a polyethylene tank volume of $10 \mathrm{~L}$. The sampler was set up at $1.5 \mathrm{~m}$ height and a large hood was mounted on the sampler to keep out rain. The use of this sampler, which does not require electricity, is advantageous at high elevations and has been used on Mt. Fuji as well as on Mt. Tateyama (Dokiya et al., 2001; Watanabe et al., 2006, 2010). Fog collection efficiency depends on the frequency of foggy weather, and the amount of fog deposition on the forest canopies is affected by wind speed and fog particle size (Lovett, 1984; Kobayashi et al., 2001). A monofilament-type passive fog water sampler has been suggested as a good proxy surface of coniferous vegetation to evaluate the water supply from fog (Mueller and Imhoff, 1989; Scholl et al., 2007; Fischer and Still, 2007). Thus, we calculated the amount of fog water deposition per surface area based on the amount of fog water collected by the passive sampler and regarded this as total fog water per unit area. The amount of fog water deposition was calculated as the amount of water in the reservoir bottle divided by the projected surface area of the total Teflon wire $(0.2 \mathrm{~mm}$ [wire radius] $\times 350 \mathrm{~mm}$ [wire length] $\times 513$ [number of wires])

\section{THROUGHFALL COLLECTION}

To measure the throughfall of the $P$. pumila canopy with a maximum height lower than $0.8 \mathrm{~m}$, we made moveable gutter-type bulk precipitation collectors (Fig. 2). Each of these collectors was $10 \times 40 \mathrm{~cm}$. The surface of the collectors was specially coated with fluoropolymer film (ASF-110, Chukoh chemical industries, LTD.,
Tokyo, Japan) to facilitate the movement of the water into a reservoir. Each reservoir was made of thick polyethylene film and was completely covered with aluminum foil and a black plastic sheet to prevent water evaporation and alteration of chemical composition. Six rain collectors were placed on the vegetation floor as low as possible (about $30 \mathrm{~cm}$ above the ground) on Jododaira from late July to early October. The water samples were collected every other week. A proportion of the collected water was brought back to the laboratory for stable isotope analysis.

\section{CALCULATION OF APPARENT CANOPY INTERCEPTION}

Canopy interception is the process whereby rainfall is intercepted by the canopy (leaves, branches) of a tree. Some of the rain contacted with the vegetation surface is stored temporarily, and either evaporates into the atmosphere or falls down to the ground as drops.

The apparent canopy interception (ACI) rate was calculated as follows:

$$
\mathrm{ACI}=(\mathrm{Pg}-\mathrm{T}) / \mathrm{Pg} \times 100,
$$

where $\mathrm{Pg}$ is the amount obtained by the bulk rain collector at the monitoring tower and $\mathrm{T}$ is throughfall estimated by each throughfall collector. This equation includes the effects of fog water impaction. Stem flow was not considered in this study because no stem was erected (Fig. 2, part b), and we had verified that the amount of stem flow was negligible in a preliminary experiment.

\section{ISOTOPE ANALYSIS}

Hydrogen and oxygen isotope ratios of all the samples were measured using a mass spectrometer (Micromass, model PRISM). Samples were prepared using $\mathrm{H}_{2} \mathrm{O}-\mathrm{H}_{2}$ equilibration with a hydrophobic platinum catalyst for $\delta \mathrm{D}$ (Coleman et al., 1982) and $\mathrm{H}_{2} \mathrm{O}-\mathrm{CO}_{2}$ equilibration for $\delta^{18} \mathrm{O}$ (Epstein and Mayeda, 1953). Stable isotope results were expressed with respect to Vienna standard mean ocean water in $\delta$ units $(\%)$ :

$$
\begin{aligned}
\delta^{18} \mathrm{O}= & \left\{\left[\left({ }^{18} \mathrm{O} /{ }^{16} \mathrm{O}\right) \text { sample }-\left({ }^{18} \mathrm{O} /{ }^{16} \mathrm{O}\right) \text { standard }\right]\right. \\
& \left./\left({ }^{18} \mathrm{O} /{ }^{16} \mathrm{O}\right) \text { standard }\right\} \times 10^{3}(0 / 00)
\end{aligned}
$$

$$
\begin{aligned}
\delta \mathrm{D}= & \{[(\mathrm{D} / \mathrm{H}) \text { sample }-(\mathrm{D} / \mathrm{H}) \text { standard }] /(\mathrm{D} / \mathrm{H}) \text { standard }\} \\
& \times 10^{3}(0 / 00)
\end{aligned}
$$


TABLE 1

Altitude and precipitation at Jodo-daira, Tengu-daira, and Toyama.

\begin{tabular}{|c|c|c|c|c|c|}
\hline \multirow[b]{2}{*}{ Year } & \multirow[b]{2}{*}{ Site } & \multirow[b]{2}{*}{ Elevation (m) } & \multicolumn{3}{|c|}{ Precipitation $\left(\mathrm{mm} \mathrm{month}{ }^{-1}\right)$} \\
\hline & & & July & August & September \\
\hline \multirow[t]{3}{*}{2006} & Jodo-daira & 2840 & - & 100.4 & 412.4 \\
\hline & Tengu-daira & 2300 & 1469.0 & 36.0 & 361.0 \\
\hline & Toyama & 13 & 569.5 & 113.0 & 126.0 \\
\hline \multirow[t]{3}{*}{2007} & Jodo-daira & 2840 & 492.9 & 326.8 & 420.1 \\
\hline & Tengudaira & 2300 & 421.0 & 507.0 & 420.0 \\
\hline & Toyama & 13 & 117.0 & 122.5 & 126.0 \\
\hline \multirow[t]{3}{*}{2008} & Jodo-daira & 2840 & 469.4 & 465.4 & 232.5 \\
\hline & Tengu-daira & 2300 & 330.5 & 539.0 & 280.0 \\
\hline & Toyama & 13 & 240.5 & 262.5 & 185.0 \\
\hline
\end{tabular}

where oxygen and hydrogen isotope ratios are expressed by $\delta^{18} \mathrm{O}$ and $\delta \mathrm{D}$, respectively. The $\left({ }^{18} \mathrm{O} /{ }^{16} \mathrm{O}\right)$ sample or $\mathrm{D} / \mathrm{H}$ sample is the isotopic ratio in the sample water, and the $\left({ }^{18} \mathrm{O} /{ }^{16} \mathrm{O}\right)$ standard or $\mathrm{D} / \mathrm{H}$ standard is the isotopic ratio in standard mean ocean water. The precision was $\pm 0.1 \%$ for $\delta^{18} \mathrm{O}$ and $\pm 1.5 \%$ for $\delta \mathrm{D}$.

\section{Result}

\section{RAINFALL}

The amount of rainfall varied considerably according to altitude and year (Table 1). During 2006-2008, the mean monthly (August and September) rainfall at Jodo-daira, Tengu-daira, and Toyama were $0.45 \mathrm{~mm} \mathrm{~h}^{-1}, 0.50 \mathrm{~mm} \mathrm{~h}^{-1}$, and $0.22 \mathrm{~mm} \mathrm{~h}^{-1}$, respectively. The amount of rainfall at the two mountain sites was twice the amount of that at the lowland site. The rainfall at Tengudaira in August 2006 was $0.05 \mathrm{~mm} \mathrm{~h}^{-1}$, which was the lowest in the three years.

\section{FOG AND DEW DEPOSITION}

The relative humidity at Jodo-daira in August 2006 and August 2008 are shown in Figure 3 (parts a and b). Despite the differences in rainfall between August 2006 and August 2008 (Table 1), the patterns of daily change in relative humidity were similar between the years, with the relative humidity almost reaching $100 \%$ in the late afternoon. The drenched period is also long at Jodo-daira (Fig. 3, part c). The data suggest that the surface was drenched, on average, for about one-third of the day, and that during $60 \%$ of the days in August, the surface was drenched in the evening (19:00 to 22:00).

The relationships between wind velocity and direction during periods of rain and high humidity periods (defined as no rain and relative humidity more than $90 \%$ ) and the remaining periods (no rain and relative humidity less than 90\%) in August 2008 are shown in Figure 4. These data show the averages of every $10 \mathrm{~min}$. The mean wind velocity in August 2008 was $4.4 \mathrm{~m} \mathrm{~s}^{-1}$, and the maximum wind velocity was $16.8 \mathrm{~m} \mathrm{~s}^{-1}$. The mean wind velocity during rain periods and high humidity periods was $4.0 \mathrm{~m} \mathrm{~s}^{-1}$ and $4.7 \mathrm{~m} \mathrm{~s}^{-1}$, and the maximum wind velocity was $16.0 \mathrm{~m} \mathrm{~s}^{-1}$ and $16.8 \mathrm{~m} \mathrm{~s}^{-1}$, respectively. During observation periods in August 2008 , the wind was blowing mainly from the southwest, $20 \%$ of the time during rain period and $22 \%$ of the time during high humidity periods. The southwest of this site is a part of the wall of Tateyama caldera, which forms a steep, long slope. These wind directions suggest that upslope fog formed by moist air masses come up from the lower part of caldera.
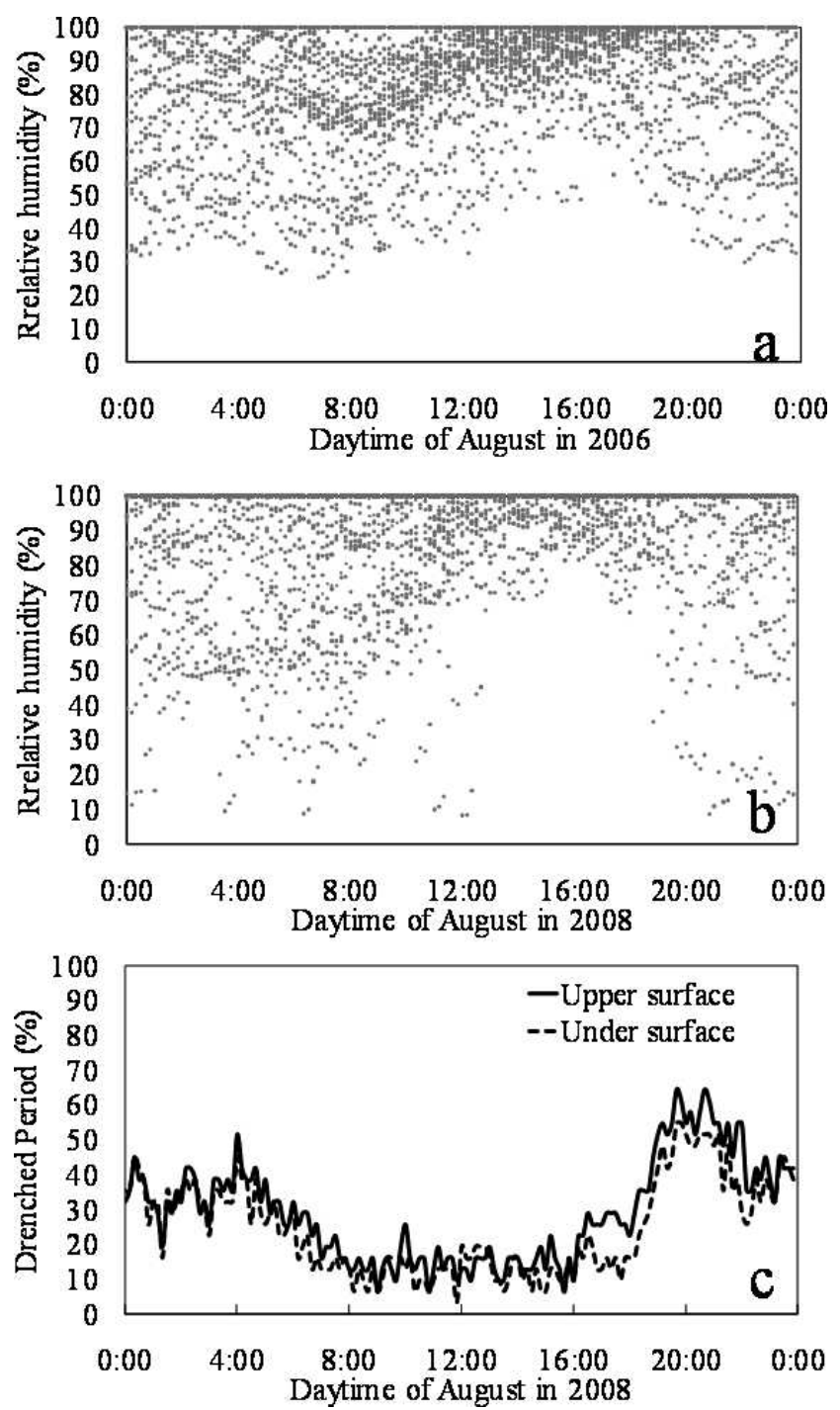

FIGURE 3. Relative humidity in (a) August 2006 and (b) August 2008. c) Drenched period $(\%)$ of the upper surfaces and under surfaces of leaves as measured by wetness sensors at Jodo-daira in August 2008. The drenched period was defined as the proportion that the wetness value was over $90 \%$ each time during a month.

During August and September in 2007-2008, the mean monthly fog deposition collected by the passive thin string sampler was $0.14 \mathrm{~mm} \mathrm{~h}^{-1}$ (range, $0.09-0.20 \mathrm{~mm} \mathrm{~h}^{-1}$ ), which is about $30 \%$ of rain deposition (mean, $0.45 \mathrm{~mm} \mathrm{~h}^{-1}$; range, $0.32-0.61 \mathrm{~mm} \mathrm{~h}^{-1}$ ).

\section{THROUGHFALL AND GROSS PRECIPITATION}

The amount of gross precipitation and throughfall at Jododaira in 2007, 2008, and 2009 is shown in Table 2. We assumed that the amount collected by the bulk rain collector at the monitoring tower was gross precipitation. When the rain collector was blown by strong winds, and the data were lost, we considered the mean value of the bulk rain collectors set up on the two slopes as the gross precipitation. When the values of the bulk rain collectors were compared with that of the tipping bucket rain gauge, the former obtained about $20 \%$ more precipitation than the latter. There was considerable rain in 2007, and the reservoirs sometimes overflowed with water, which means that our precipitation values at Jodo-daira are likely to be underestimates. 

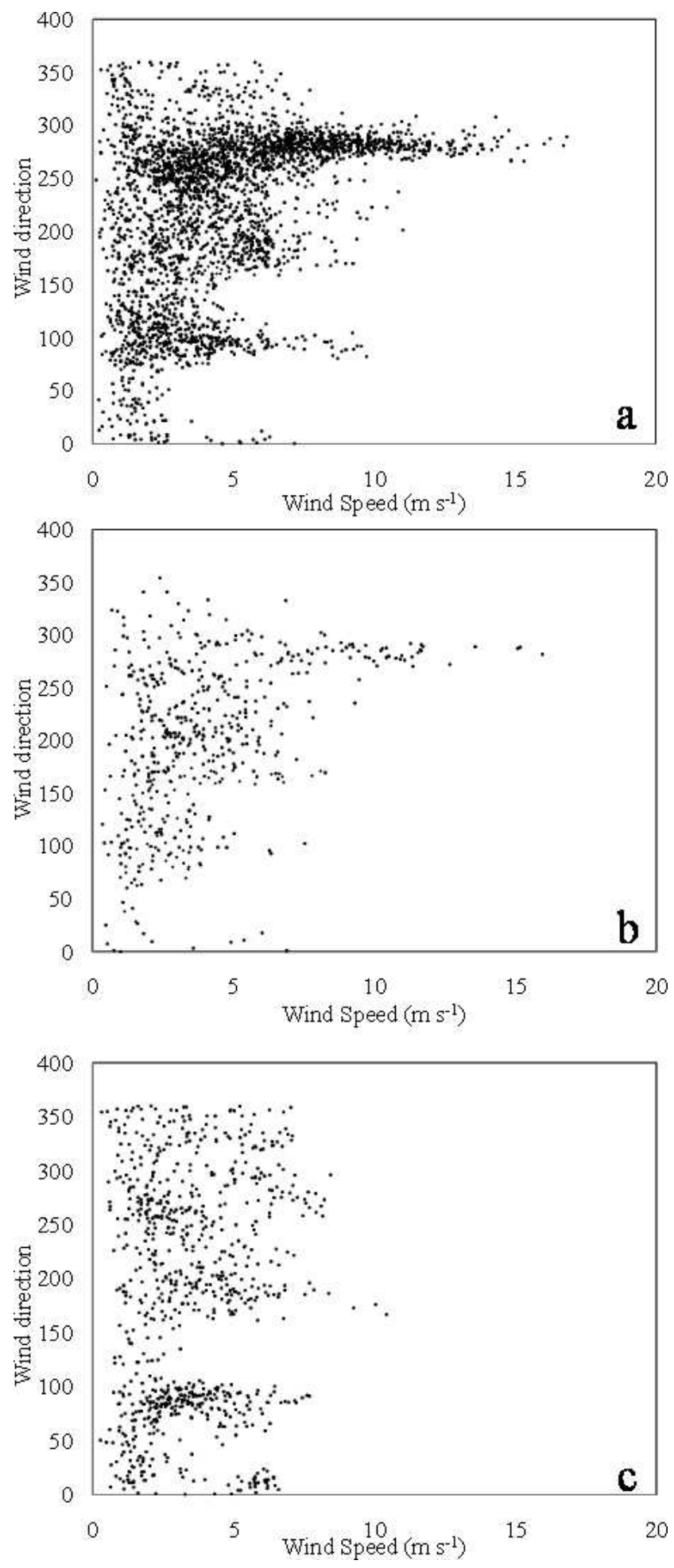

FIGURE 4. The relationship between wind direction and wind speed in August 2008 for (a) fog period (no rain and humidity more than $90 \%$ ), (b) rain period, and (c) the period of no rain and relative humidity lower than $\mathbf{9 0} \%$. One point represents the average of $10 \mathrm{~min}$.

Figure 5 shows the relationship between gross precipitation and throughfall. The amount of throughfall increased with increasing gross precipitation. The mean ACI of the $P$. pumila canopy changed considerably year by year: $80.0 \%$ (range, -57.6 to $96.7 \%$; $\mathrm{SD}=34.7 \%$ ) in $2006,37.4 \%$ (range, -315.2 to $93.0 \%$; SD $=78.3 \%$ ) in 2007 , and $65.7 \%$ (range, -101.1 to $98.0 \%$; $\mathrm{SD}=$ $52.6 \%$ ) in 2008 .
ISOTOPIC COMPOSITION OF FOG WATER, RAINFALL AND THROUGHFALL

Figure 6 shows the relationship between $\delta^{18} \mathrm{O}$ and $\delta \mathrm{D}$ for fog water, gross precipitation, and throughfall water. The gross precipitation was $-13.5 \%$ for $\delta^{18} \mathrm{O}$ and $-93.5 \%$ for $\delta \mathrm{D}$, the fog water was $-11.7 \%$ for $\delta^{18} \mathrm{O}$ and $-83 \%$ for $\delta \mathrm{D}$, and the throughfall was $-12.6 \%$ for $\delta^{18} \mathrm{O}$ and $-88 \%$ for $\delta \mathrm{D}$. Stable isotope ratios of rain and fog were different, and the ratios of throughfall were intermediate.

\section{Discussion}

\section{RAINFALL AT JODO-DAIRA}

The effect of altitude on rainfall is one of the most important subjects for hydrological research. Wehren et al. (2010) suggested that the effect of topography on approaching air masses is crucially important in determining precipitation volumes but that there is no simple causal relationship between altitude and precipitation volume. In this sense, the Japan Alps are quite unique compared with the continental Alps (e.g. Wehren et al., 2010). In the Japan Alps, air above the warm sea rises when it meets the adjacent steep mountains and strong monsoons bring high concentrations of water vapor. This situation causes strong orographic-induced precipitation in the mountains. As shown in Figure 7, a strong linear relationship between rainfall and altitude was detected, regardless of year. The amount of rainfall increased with increasing altitude without a plateau. Therefore, it is suggested that the air humidity was almost saturated, even at the top of the mountains, during precipitation events. This abundant supply of humid air mass explains the high frequency of fog generation at the top of the Japan Alps.

\section{CANOPY INTERCEPTION}

Throughfall can be divided into two main parts. One part is the rain that reaches the forest floor directly, without touching the forest canopy. The other part is the rain that has some contact with the canopy. Because these were difficult to precisely divide, they were both treated as throughfall. However, as the leaf area density of $P$. pumila canopy is quite large $\left(4-6 \mathrm{~m}^{2} \mathrm{~m}^{-3}\right)$ (Kajimoto, 1989), a large proportion of the rainfall should have contact with the needles. We found that the mean proportion of rain intercepted by $P$. pumila canopy was $47.7 \%$ over the 3 years and this value was higher than that of other forest canopies at lower altitudes (e.g. the values for evergreen confers, Cryptomeria japonica and Chamaecyparis obtusa, are about 16-35\% [Tanaka et al., 2005]; evergreen broad-leaved tree, Lithocarpus edulis, is 6-37\% [Sato et al., 2002]; deciduous broad-leaved tree, Fagus crenata, is 32\% [Inoue et al., 1993; mountain coniferous forest is $32 \%$ [Abies veitchii, $1705 \mathrm{~m}$ a.s.1.]; and mountain deciduous broad-leaved forest is $19 \%$ [Betula platyphylla, $1610 \mathrm{~m}$ a.s.l.] [Muramoto et al., 2007]). The high interception ratio of the $P$. pumila canopy may be attributed to the high leaf area density. During a rainfall event, the dense canopy intercepts precipitation and the stored water evaporates from the needle surfaces continuously (Rutter, 1967).

\section{FOG DEPOSITION ON THE PINE CANOPY}

On average, the canopy interception at Jodo-daira was reasonably high. However, the amount of throughfall was sometimes larger than the gross precipitation (22 out of 113 samples in the three years). Similar patterns have been reported in 
TABLE 2

Summary of precipitation, throughfall, and fog deposition in summer (August and September) at Pinus pumilia stands at Jodo-daira.

\begin{tabular}{lccc}
\hline \hline \multicolumn{1}{c}{ Year } & 2006 & 2007 & 2008 \\
\hline Gross precipitation $\left(\mathrm{mm} \mathrm{month}^{-1}\right)$ & 256.4 & 373.5 & 349.0 \\
Throughfall $\left(\mathrm{mm} \mathrm{month}{ }^{-1}\right)$ & 51.2 & 233.9 & 119.6 \\
Fog deposition $\left(\mathrm{mm}\right.$ month $\left.^{-1}\right)$ & - & 115.3 & 80.1 \\
Canopy interception (\%) & 80.0 & 37.4 & 65.7 \\
Canopy interception range (\%) & -57.6 to 96.7 & -315.2 to 93 & -101.1 to 98 \\
\hline
\end{tabular}

other high-elevation regions (Prada et al., 2009; Kobayashi et al., 1998) and in areas where fog is often observed (Ewing et al., 2009). Igawa et al. (2002) found that the frequency of fog events, and the amount of throughfall, increased with increasing altitude on Mt. Oyama in Japan. Kobayashi et al. (1999) reported that fog events were more likely when relative humidity was over $80 \%$. The chance of a fog event exceeded $70 \%$ when the relative humidity was $86 \%$ or more. We observed fog events nearly every day during our fieldwork on Jodo-daira. As shown in Figure 3, the relative humidity at Jodo-daira was reasonably high and frequently saturated, even in the absence of rain. The LAI of the $P$. pumila canopy is quite large and we found that the leaf surfaces were drenched for long periods when there was no rainfall. This suggests that the needle leaves of $P$. pumila worked as efficient fog water collectors. We also found a significant positive relationship between the amounts of fog deposition and throughfall (Fig. 8). Sometimes the amount of throughfall exceeded that of gross precipitation, for instance, when there was little rainfall. During these periods, it is suggested that the $P$. pumila canopy collected throughfall water by fog capture.

Fog precipitation may occur when fog passes through the forest canopy and intercepted fog droplets coalesce on needle surfaces and drip to the forest floor. Went (1995) described how tiny leaf surfaces, such as pine or redwood needles, are very effective for fog water capture.

The $\delta^{18} \mathrm{O}$ and $\delta \mathrm{D}$ of fog and rain were consistently different as shown in Table 3 and Figure 6. The composition of fog was isotopically enriched compared with rain. Similar results were also reported in other previous studies (e.g. Dawson, 1998; Liu et al., 2007; Scholl et al., 2007). In this study, for isotopic differences between monthly weighted average ratio of rain and fog, the

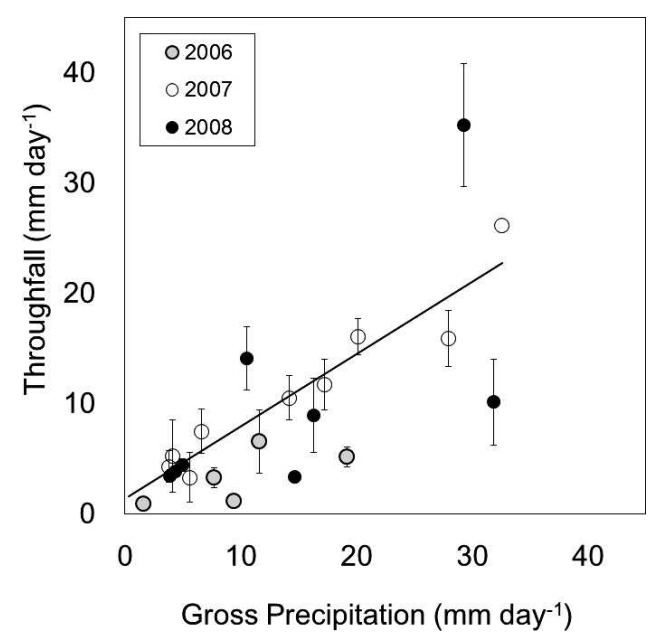

FIGURE 5. The relationship between gross precipitation and throughfall in summer (August and September) at Jodo-daira. Points are the mean values, and error bars show the standard error of four rain collectors in 2006 and six rain collectors in 2007 and $2008\left(R^{2}=0.58 ; y=0.66 x+0.25\right)$. maximum was $4.5 \%$ for $\delta^{18} \mathrm{O}$ and $45 \%$ for $\delta \mathrm{D}$, and the minimum was $0.9 \%$ and $\delta^{18} \mathrm{O}$ and $1.7 \%$ for $\delta \mathrm{D}$. Scholl et al. (2010) found that differences between fog and rain isotopes are largest when rain is from synoptic-scale storms, and fog or orographic cloud water is generated locally. Smaller isotopic differences have been observed between rain and fog on mountains with orographic clouds, but only a few studies have been conducted (Scholl et al., 2010). The $\delta^{18} \mathrm{O}$ and $\delta \mathrm{D}$ of throughfall water was higher than those of rainfall but lower than those of fog deposition (Fig. 6). Therefore, it is inferred that the throughfall was a mixture of rain and fog. To estimate the mixing ratio, we applied a simple isotope mixing model. In this model, one end member is fog and the other end member is gross precipitation:

$$
\delta^{18} \mathrm{O}_{\mathrm{Tf}}=\delta^{18} \mathrm{O}_{\mathrm{Pg}} \times(1-\mathrm{a})+\delta^{18} \mathrm{O}_{\mathrm{F}} \times \mathrm{a},
$$

where $\delta^{18} \mathrm{OT}_{\mathrm{f}}$ is the oxygen isotopic composition of the throughfall water, $\delta^{18} \mathrm{O}_{\mathrm{Pg}}$ is the oxygen isotopic composition of the gross precipitation, $\delta^{18} \mathrm{O}_{\mathrm{F}}$ is the oxygen isotopic composition of the fog water collected by the passive string fog collector, and a was the contribution ratio of fog to throughfall. Based on this model, the mean contribution to the throughfall of fog was about 35\% (14$98 \%$ ). The weighted average ratio of oxygen and hydrogen isotopes in the three years was $-13.5 \%$ o for rain, $-12.6 \%$ for throughfall, and $-11.7 \%$ o for fog (Table 3 ). However, there were some events when the contribution ratio of the isotopes was less than zero or more than one. Throughfall ${ }^{18} \mathrm{O}$ enrichment could be observed because of the high canopy interception of $P$. pumila at Jodo-daira. DeWalle and Swistock (1994) reported that average throughfall ${ }^{18} \mathrm{O}$ enrichment of a pine forest in central Pennsylvania,

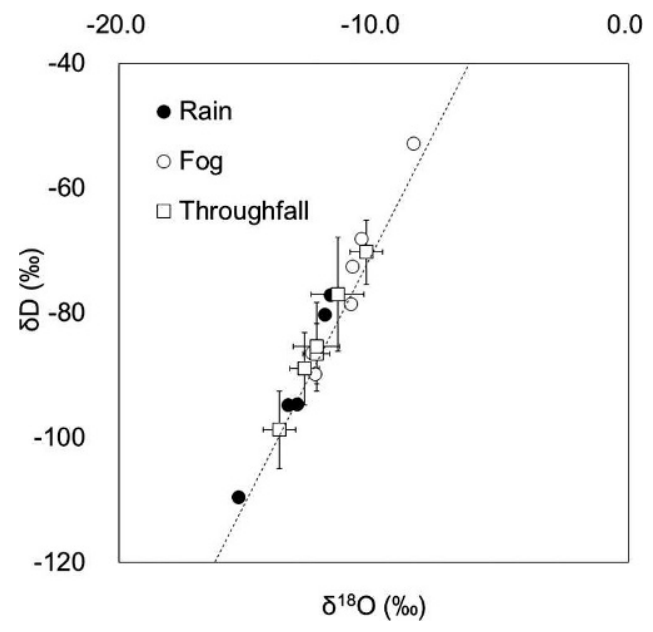

FIGURE 6. The relationships between $\delta D$ and $\delta^{18} O$ of rainfall( $\odot$ ), throughfall( $\square$ ), and fog $(\bigcirc)$ deposition for summer (JulySeptember) at Jodo-daira in 2007 and 2008. Each point shows the precipitation-weighted average value of a month. Error bars show the standard deviation of six throughfall collectors in each month. The dotted line shows the global meteoric water line $\left(\delta \mathrm{D}=8 \times \delta^{18} \mathrm{O}\right.$ + 10; Craig, 1961). 


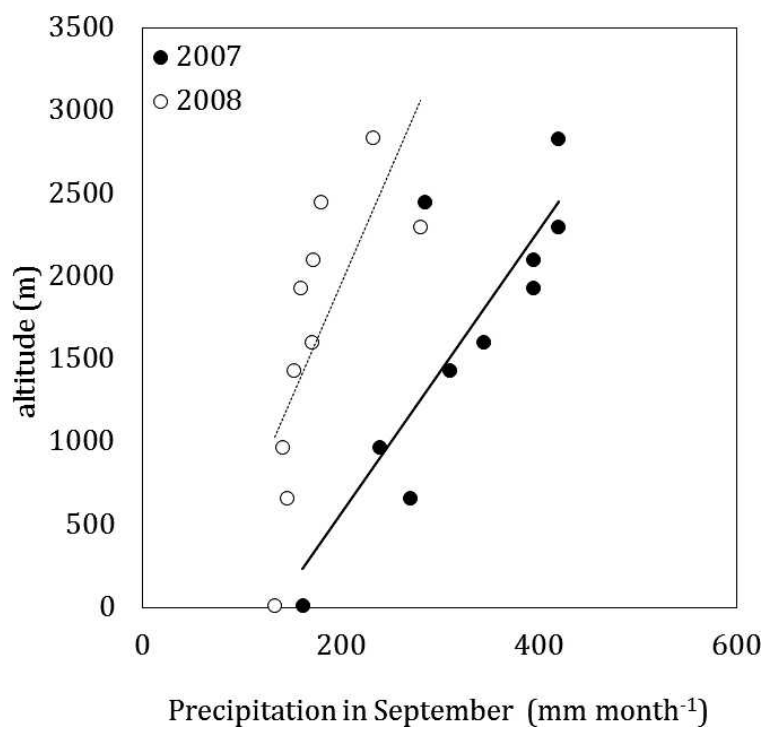

FIGURE 7. The relationship between rainfall and altitude in 2007 and 2008. and the dotted line represent September $2007\left(R^{2}=\right.$ 0.52, $y=13.86 x-821.8)$. $\bigcirc$ and the solid line represent September $2008\left(R^{2}=0.71, y=8.57 x-1146.8\right)$. Except for Jodo-daira, the rainfall data are from Honoki and Watanabe (2008) and Honoki et al. (2009).

U.S.A., was $0.32 \%$. The high humidity at Jodo-daira may explain why the value of throughfall ${ }^{18} \mathrm{O}$ enrichment in our study was smaller than this reported value. Overall, this result supports our hypothesis that fog water greatly contributes to throughfall water. It also suggests that the amount of throughfall was not simply determined by the input of precipitation and fog but was also affected by the evaporation process from the canopy.

\section{Conclusion}

Our results showed that fog deposition on the P. pumila canopy had a large contribution to the amount of throughfall during the snow-free period on Mt. Tateyama, central Japan. The dense $P$. pumila canopy intercepted a large proportion of the gross precipitation, and the interception of gross precipitation increased with the amount of gross precipitation. The mean rainfall interception rate was $47.7 \%$ across the three years, and this was higher than that of other tree species canopies at lower altitudes. We found that the canopy efficiently captured fog, and supplied it as throughfall water, even in the absence of rainfall. The presence of the $P$. pumila canopy may therefore stabilize the water supply to the soil surface. The high efficiency of fog capture can be attributed largely to the canopy surface area and the microtopography of the ground surface, while the large contribution of fog deposition to the amount

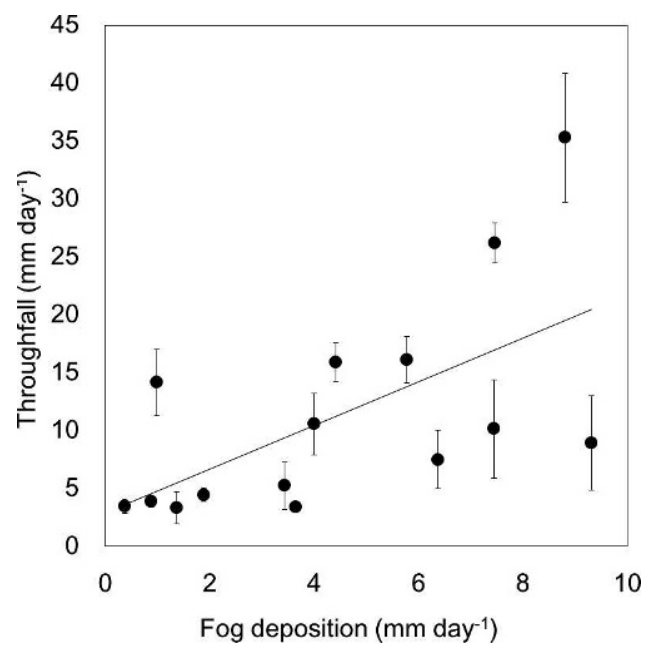

FIGURE 8. The relationship between throughfall and fog deposition in 2007 and 2008. Error bars show the standard error of six throughfall collectors $\left(R^{2}=0.37, y=1.89 x+2.91\right)$.

of throughfall can be explained by the high humidity in the Japan Alps due to their particular geography. Overall, the presence of the $P$. pumila canopy can be predicted to have a significant influence on the local hydrological processes of the high mountain ecosystem.

\section{Acknowledgments}

We thank the late Prof. Hiroshi Satake, the University of Toyama, for his valuable advice, encouragement, and technical support throughout this study. We also thank Koichi Watanabe, Hideharu Honoki, Hajime Iida, Kyoichi Otsuki, and Eisuke Niwa, and the members of the University of Toyama and the Tateyama Murodo Sanso for their support in this study. This work was supported in part by a Grant-in-Aid for Scientific Research from the Ministry of Education, Culture, Sports, Science and Technology (No. 18310022) and Global COE Program (Center of excellence for Asian conservation ecology as a basis of humannature mutualism), MEXT, Japan. Chubu Region Environmental Office, Toyama Prefecture and the Toyama District Forest Office granted admittance for research on Mt. Tateyama.

\section{References Cited}

Chang, S., Yeh, C., Wu, M., Hsia, Y., and Wu, J., 2006: Quantifying fog water deposition by in situ exposure experiments in a mountainous coniferous forest in Taiwan. Forest Ecology and Management, 224: 11-18.

Coleman, M. L., Stephard, T. J., Durnham, J. J., Rouse, J. E., and Moore, G. R., 1982: Reduction of water with zinc for hydrogen isotope analysis. Analytical Chemistry, 54: 993-995.

TABLE 3

Volume-weight average (VWA) and $\delta^{18} \mathrm{O}$ and $\delta \mathrm{D}$ for gross precipitation, throughfall, and fog deposition at Jodo-daira in summer (August and September).

\begin{tabular}{|c|c|c|c|c|}
\hline \multirow[b]{2}{*}{ Year } & \multicolumn{2}{|c|}{$\delta^{18} \mathrm{O}(\%)$} & \multicolumn{2}{|c|}{$\delta \mathrm{D}(\%)$} \\
\hline & 2007 & 2008 & 2007 & 2008 \\
\hline Gross precipitation VWA & -14.1 & -12.8 & -97 & -89 \\
\hline Gross precipitation range & -16.1 to -0.8 & -15.5 to -8.7 & -118 to -63 & -117 to -49 \\
\hline Throughfall VWA & -12.5 & -12.7 & -88 & -89 \\
\hline Throughfall range & -15.2 to -8.8 & -15.8 to -7.9 & -110 to -49 & -116 to -46 \\
\hline Fog deposition VWA & -11.8 & -11.6 & -86 & -79 \\
\hline Fog deposition range & -15.5 to -7.5 & -12.5 to -7.6 & -117 to -50 & -87 to -46 \\
\hline
\end{tabular}


Craig, H., 1961: Isotopic variations in meteoric waters. Science, 133: $1702-03$.

Dawson, T. E., 1998: Fog in the California redwood forest: ecosystem inputs and use by plants. Oecologia, 117: 476-485.

DeWalle, D. R., and Swistock, B. R., 1994: Differences in ${ }^{18} \mathrm{O}$ content of throughfall and rainfall in hardwood and coniferous forests. Hydrological Processes, 8: 75-82.

Dokiya, Y., Yoshikawa, T., Komada, T., Suzuki, I., Naemura, A., Hayashi, K., Naoe, H., Sawa, Y., Sekiyama, T., and Igarashi, Y., 2001: Atmospheric chemistry at the summit of Mt. Fuji: a challenging field for analytical chemists. Analytical Science, 17, suppl.: i809-i812.

Epstein, S., and Mayeda, T., 1953: Variation of ${ }^{18} \mathrm{O}$ content of waters from natural sources. Geochimica et Cosmochimica Acta, 4: $213-224$.

Ewing, H. A., Weathers, K. C., Templer, P. H., Dawson, T. E., Firestone, M. K., Elliott, A. M., and Boukili, V. K. S., 2009: Fog water and ecosystem function: Heterogeneity in a California redwood forest. Ecosystems, 12: 417-433.

Fischer, D. T., and Still, C. J., 2007: Evaluating patterns of fog water deposition and isotopic composition on the California Channel Islands. Water Resources Research, 43: W04420, doi:1029/2006WR005124.

Gower, S. T., Gholz, H. L., Nakane, K., and Baldwin, V. C., 1994: Production and carbon allocation patterns of pine forest. Ecological Bulletins, 43: 115-135.

Holder, C. D., 2004: Rain interception and fog precipitation in a tropical montane cloud forest of Guatemala. Forest Ecology and Management, 190: 373-384.

Honoki, H., and Watanabe, K., 2008: Acid rain observation report at different altitudes on the Mt. Tateyama (2006). Research Report of Toyama City Science Museum, 31: 105-112.

Honoki, H., Watanabe, K., and Kometani, M., 2009: Acid rain observation report at different altitudes on the Mt. Tateyama (2007). Research Report of Toyama City Science Museum, 32: 125-131.

Igawa, M., Tsutsumi, Y., and Okochi, H., 2002: High frequency and large deposition of acid fog on high elevation. Environmental Science and Technology, 32: 1-6.

Inoue, K., Yokota, N., Murai, H., Kumagai, N., and Mochizuki, J., 1993: Rain and percolation waters of beech and Japanese cypress forests in the foot of Mt. Fuji and neutralization of acid rain by a beech tree. Japanese Society of Soil Science and Plant Nutrition, 64: 264-274.

Kajimoto, T., 1989: Aboveground biomass and litterfall of Pinus pumila scrubs growing on the Kiso mountain range in central Japan. Ecological Research, 4: 55-69.

Kajimoto, T., 1994: Aboveground net production and dry matter allocation of Pinus pumila forests in the Kiso mountain range, central Japan. Ecological Research, 9: 193-204.

Kobayashi, T., Nakagawa, Y., Tamaki, M., Hiraki, T., and Akawa, M., 1998: Altitudinal distribution of the acidic deposition rate onto canopies of Cypomeria japonica at Mt. Rokko. Report of the Hyogo Prefectural Institute of Environmental Science, 30: 41-50.

Kobayashi, T., Nakagawa, Y., Tamaki, M., Hiraki, T., Akawa, M., and Shoga, M., 1999: Estimation of acid deposition to forest canopies via cloud water by means of throughfall measurements and cloud water collection-Measurements in Cryptomeria japonica stands at Mt. Rokko in Kobe, western Japan. Environmental Science, 12: 399-411.

Kobayashi, T., Nakagawa, Y., Tamaki, M., Hiraki, T., and Akiwa, M., 2001: Cloud water deposition to forest canopies of Cryptomeria japonica at Mt. Rokko. Water, Air, and Soil Pollution, 130: 601-606.

Liu, W. J., Liu, W. Y., Li, P. J., Gao, L., Shen, Y. X., Wang, P. Y., Zhang, Y. P., and Li, H. M., 2007: Using stable isotopes to determine sources of fog drip in a tropical seasonal rain forest of Xishuangbanna, SW China. Agricultural and Forest Meteorology, 143: 80-91.

Lovett, M. G., 1984: Rate and mechanism of cloud water deposition to subalpine balsam fir forest. Atmospheric Environment, 18: 361-371.

Mueller, S. F., and Imhoff, R. E., 1989: Inferring cloud deposition to a forest canopy using a passive cloudwater collector. Geophysical Research Letters, 16: 683-686.
Muramoto, M., Nara, M., Asari, T., and Suzuki, K., 2007: Hydrochemical cycle of forest ecosystem in the Norikura Highlands1. Chemical characteristic and seasonal change of throughfall in forest ecosystem. Journal of Japanese Association of Hydrological Sciences, 37: 73-83.

Okitsu, S., and Ito, K., 1983: Dynamic ecology of the Pinus pumila community of Mt. Taisetsu, Hokkaido, Japan. Journal of the Graduate School of Environmental Science, Hokkaido University, Sapporo, 6: 151-184.

Prada, S., Menezes de Sequeira, M., Figueria, C., and Oliveria de Silva, M., 2009: Fog precipitation and rainfall interception in the natural forests of Madeira Island (Portugal). Agricultural and Forest Meteorology, 149: 1179-1187.

Richardson, D. M., and Rundel, P. W., 1998: Ecology and biogeography of Pinus: an introduction. In Richardson, D. M. (ed.), Ecology and Biogeography of Pinus. Cambridge and New York: Cambridge University Press, 3-46.

Rutter, A. J., 1967: An analysis of evaporation from a stand of Scots pine. In Sopper, W. E., and Lull, H. W. (eds.), Proceedings of the International Symposium on Forest Hydrology. Oxford: Pergamon Press, 403-417.

Sato, Y., Otsuki, K., and Ogawa, S., 2002: Estimation of annual canopy interception by Lithocarpus edulis Nakai. Bulletin of the Kyushu University Forest, 83: 15-29.

Scholl, A. M., Gimbelluca, T. W., Gingerich, S. B., Nullet, M. A., and Loope, L. L., 2007: Cloud water in windward and leeward mountain forests: the stable isotope signature of orographic cloud water. Water Resources Research, 43: W12411.1-W12411.13.

Scholl, M., Eugster, W., and Burkard, R., 2010: Understanding the role of fog in forest hydrology: stable isotopes as tools for determining input and partitioning of cloud water in montane forests. Hydrological Processes, 25: 353-366.

Tanaka, N., Kuraji, K., Shiraki, K., Suzuki, M., Suzuki, M., Ohta, T., and Suzuki, M., 2005: Throughfall, stemflow and rainfall interception at mature Cyptomeria japonica and Chamaecyparis obtuse stands in Fukuroyamasawa watershed. Bulletin of the Tokyo University Forests, 113: 197-240.

Taniguchi, M., Nakayama, T., Tase, N., and Shimada, J., 2000: Stable isotope studies of precipitation and river water in the Lake Biwa basin, Japan. Hydrological Processes, 14: 539-556.

Wada, N., 2007: Fine-scale species richness of alpine fellfield plant communities in a middle-latitude mountain of central Japan: influences of alpine dwarf pine and substrate properties. Far Eastern Studies, 6: 31-34.

Watanabe, K., Takebe, Y., Sode, N., Igarashi, Y., Takahashi, H., and Dokiya, Y., 2006: Fog and rain water chemistry at Mt. Fuji: a case study during the September 2002 campaign. Atmospheric Research, 82: 652-662.

Watanabe, K., Honoki, H., Iwai, A., Tomatsu, A., Noritake, K., Miyashita, N., Yamada, K., Yamada, H., Kawamura, H., and Aoki, K., 2010: Chemical characteristics of fog water at Mt. Tateyama, near the coast of the Japan Sea in central Japan. Water, Air, and Soil Pollution, 211: 379-393.

Wehren, B., Weingartner, R., Schädler, B., and Viviroli, D., 2010: General characteristics of alpine waters. In Bundi, U. (ed.), Alpine Waters. Handbook of Environmental Chemistry, vol. 6. Heidelberg: Springer, 278 pp.

Went, F. W., 1995: Fog, mist, dew, and other sources of water. In: Yearbook of Agriculture. Washington D.C.: U.S. Department of Agriculture, 103-109.

Yanagimachi, O., and Ohmori, H., 1991: Ecological status of Pinus pumila scrub and the lower boundary of the Japanese alpine zone. Arctic and Alpine Research, 23: 424 435.

Yoshino, M., 1975: Climate in a Small Area-An Introduction to Local Meteorology. Tokyo: University of Tokyo Press, 549 pp.

Zhang, W., Cheng, B., Hu, Z., An, S., Xu, Z., Zhao, Y., Cui, J., and $\mathrm{Xu}, \mathrm{Q}$., 2010: Using stable isotopes to determine the water sources in alpine ecosystems on the east Qinghai-Tibet plateau, China. Hydrological Processes, 24: 3270-3280. 